\title{
Green Products Image in the Perspective of Young Consumers
}

\author{
Irma Ramadhani ${ }^{1,}$ Jeni Wulandari ${ }^{2 *}$ Ghia Subagja $^{3}$ \\ ${ }^{1,2,3}$ Business Administration Department, Uniiversitas Lampung \\ "Corresponding author. Email: jeni.wulandari@fisip.unila.ac.id
}

\begin{abstract}
Green products are becoming a trend for the business world to be involved in environmental conservation. However, few studies have examined its effect on corporate image, especially among young people in developing countries. This study provides an overview of the relationship between green products and advertising on green brand image in young consumers' perspectives. A quantitative approach uses in this study to 100 samples of young consumers. Theoretical and practical support can contribute to this research in expanding the use and campaign of green products.
\end{abstract}

Keywords: Green Products, Green Advertising, Green Brand Image, Young Consumers

\section{INTRODUCTION}

The interaction between humans and their physical environment has been extensively studied, mainly related to global environmental pollution as a health problem for the international community with various underlying aspects [1]. These environmental sustainability trends, leading to consumer demands and behaviour changes, such as buying green products[2].

Green products are made from environmentally safe, recyclable, and less packaging [3]. In some developing countries, consumers are showing positive behaviour towards purchasing green products, and are also spreading in developing countries due to increased knowledge about environmental protection [2].

The report results on 3,631 consumers in Indonesia showed a similar trend; as many as 62.59 percent of consumers are willing to buy green products. The main factor in purchasing green products is the desire to participate in preserving the earth. Other factors include satisfaction with the use of green products, a good and positive image if buying green products, spontaneous purchases in supermarkets, and the coincidental factor of brands/companies that are favoured to have green products [4].

There is much previous research support that examines the buying behaviour of green products [2], [5]-[12]. However, studies that have been conducted on green products in developing countries, particularly in young consumers, are still limited [12]. In contrast, awareness for environmental care is more remarkable in young consumers [13]. The context of developing countries is important because a large part of the study of consumer behaviour towards green products comes from the West. The situational context influences the consumption decisions of green products [7].

Interestingly, it is not always the company's efforts to create green products, and disseminate information on the importance of environmental concern through advertisements delivered, can be followed up in the form of product buying behaviour by consumers [5], [7], [10]. Nevertheless, consumers positively perceive brands/companies that care about the environment [5]. This perception creates a green brand image for the company. Green brand image is the perception of a brand in the minds of consumers and is related to commitment to the environment and environmental concerns of a product or service [14].

Some research supports a positive association of how green products and advertisements can influence green brand image for the company [15], [16], [17]. The study helped to build two hypotheses in this study:

H1: Green products are positively associated with the green brand image by young consumers.

$\mathrm{H} 2$ : Green advertising is positively associated with the green brand image by young consumers. 
H3: Green products and advertising simultaneously are positively associated with the green brand image by young consumers.

Based on this background, the study offers empirical insights into green product buying behaviour among young consumers in viewing green products and advertisements on green brand images. The findings in this study contribute to the literature on how young consumers view the image of green products. The findings could allow organizations to target their marketing efforts to attract young consumers as the most prominent target consumers in developing countries such as Indonesia.

\section{METHOD}

This research is a type of explanatory research with a quantitative approach. 100 Starbucks consumer respondents in Bandar Lampung City, Lampung, Indonesia, as a sample of brands/companies focused on green products. The sample determines by accident sampling. The spread of questionnaires is done online through a google form, using WhatsApp and Instagram media applications. The Likert scale is using to measure a consumer's assessment of a statement, ranging from strongly disagreeing (1), disagreeing (2), simply agreeing (3), agreeing (4), and strongly agreeing (5).

Green products in this study measured in three natural indicators, namely composition of contents, packaging, and product perception [18]. Some statement items represent content composition indicators on green product variables, i.e., "products do not produce waste harmful to the environment," or on packaging indicators such as "recyclable product packaging." The item "trust that the products offered can minimize the impact of plastic waste" becomes one of the items in the product perception indicator.

While green advertising is measuring in two indicators: advertising and messaging [19]. One of the statement items submitted in the advertising indicator is "the company conveys information through advertising that its products are green products." Item "company provides information on the importance of maintaining the environment" as one of the statement items in the message indicator.

In the green brand image, variables indicators are the maker's image (corporate image) depicted in the example item statement "I see companies participating in reducing plastic waste." Then, the user image, with example item statement "product purchases as a form of concern for the environment." While the item "company products are safe for the environment" is one of the statements representing product image indicators [20].

Data analysis performed in several stages: descriptive analysis (gender, age, education, income per month, and consumer knowledge of the company's commitment in support of environmental sustainability, as well as the distribution of respondents' answers to variables), classical assumption tests (normality, heteroskedasticity, multicollinearity, and autocorrelation), and linear regression analysis using SPSS version 16.0 for windows.

\section{RESULT AND ANALYSIS}

\subsection{Descriptive Analysis}

Based on the results of descriptive analysis, $68.50 \%$ of respondents were dominated by women, with the most significant age of $21-27$ years $(85.4 \%)$. The last end of education is dominated by senior high school (74.6\%), with $43.8 \%$ of the most average income being Rp 500,000 - Rp 1,000,000 per month. 96.2\% of respondents already know that the company has used green products and campaigns for the use of tumblers to reduce the use of single-use plastic containers.

Meanwhile, the distribution of respondents' answers on the green product variable showed an average value of 4.12 from the highest answer assessment scale of 5 . The items above average are consumer knowledge that products use green raw materials, the availability of information warning the use of disposable packaging products, and the perception that the product uses green packaging and minimizing the use of plastic waste. At the same time, the item that obtains the lowest assessment is consumer knowledge of waste products that harm the environment.

The green advertising variable shows an average valuation of 4.13 from the highest answer assessment scale of 5 . The highest item is in the message indicator that contains information about the importance of maintaining the environment. In comparison, the items with the lowest rating are consumer knowledge about green product lifecycle information conducted on social media by companies.

The green brand image variable shows an average rating of 4.04 from the highest answer assessment scale of 5. The item with the highest rating lies in the indicator of the user's image, the purchase of the company's products to meets the lifestyle. An item with below-average ratings is also found in indicators of user image, deals with the favourite products, and the statement that consumers buy products because they care about the environment. 


\subsection{Classic Assumption Test}

\subsubsection{Normality Test}

Normal P.P Plot of Regression Standardized Residual

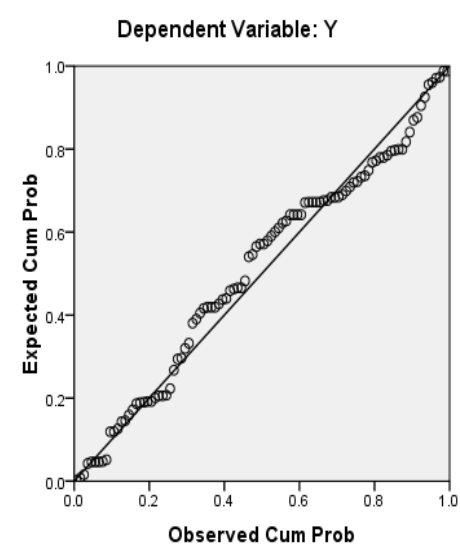

Fig. 1 Normality Test Results

Based on normal p-plot regression standardized residual in figure 1 , the variables tested are normal distribution because the dot lines follow diagonal lines. It also showed that the spread of these study questionnaires had been distributed normally and represented several parties (sub-populations). Thus, the residuals in this study have fulfilled the assumption of normality.

\subsubsection{Heteroskedasticity Test}

Based on figure 2, the pattern of data dissemination in the form of points on scatterplot does not form a pattern of setting a particular flow, concluded that there is no heteroskedasticity. Thus, the classical test of heteroskedasticity in this model is fulfilled. This test is conducted to determine the deviation from the requirements of classical assumptions in multiple linear regression wherein the regression model must be met the condition of the absence of heteroscedasticity.

Scatterplot

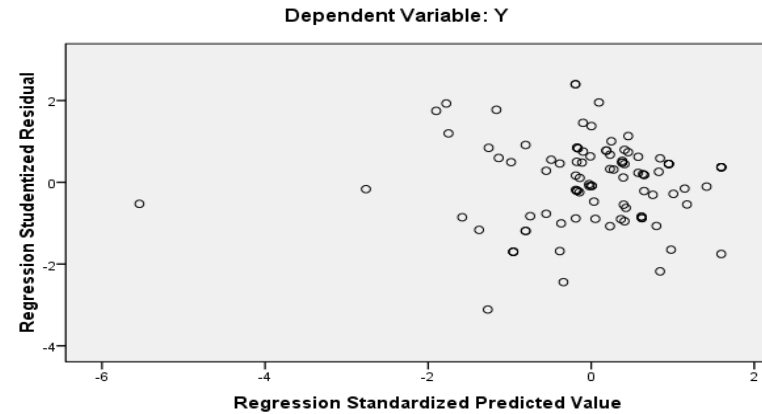

Fig. 2 Heteroskedasticity Test Results
The results of the multicollinearity test in table 1 , show that the entire free variable has a Variances Inflation Factor (VIF) value of $<10$ and a tolerance value of $>0.10$. So, it can be concluded in this study there is no multicollinearity, which means there is no correlation between free variables or independent variables, so as not to interfere with the relationship between free and predicate variables.

Table 1. Multicollinearity Test Results

\begin{tabular}{|l|r|l|}
\hline \multicolumn{1}{|c|}{ Variable } & Tolerance & \multicolumn{1}{|l|}{ VIF } \\
\hline Green Product & 0,474 & 2.111 \\
\hline Green Advertising & 0,474 & 2.111 \\
\hline
\end{tabular}

\subsubsection{Autocorrelation Test}

Durbin Watson value of 1,873 , comparison using significance value 5\%, sample number 100 (n) and the number of independent variables $2(\mathrm{k}=2)$, then in Durbin Watson table will be obtained dU value of 1.7152 and $\mathrm{dL}$ of 1.6337 . So that $\mathrm{dL}(1.7152)<\mathrm{d}$ $(1.873)>\mathrm{dU}$ (1.6337), it can be concluded that the results of the autocorrelation test in this study did not occur autocorrelation

Table 2. Autocorrelation Test Results

\begin{tabular}{|l|l|l|l|l|l|}
\hline Type & $R$ & $\begin{array}{l}\mathrm{R} \\
\text { Square }\end{array}$ & $\begin{array}{l}\text { Adjusted } \\
\mathrm{R} \text { Square }\end{array}$ & $\begin{array}{l}\text { Std. error } \\
\text { of the } \\
\text { Estimate }\end{array}$ & $\begin{array}{l}\text { Durbin- } \\
\text { Watson }\end{array}$ \\
\hline 1 & $0.790^{\mathrm{a}}$ & 0.624 & 0.617 & 2.87826 & 1.873 \\
\hline
\end{tabular}

a. Predictors: (Constant), green product, and green advertising

b. Dependent Variable: green brand image

\subsection{Multiple Linear Regression Analysis}

Table 3. Results of Multiple Linear Regression Calculations

\begin{tabular}{|c|c|c|}
\hline Type & B & Sig \\
\hline Constant & 1.825 & 0.396 \\
\hline $\begin{array}{c}\text { Green } \\
\text { Product }\end{array}$ & 0.718 & 0.000 \\
\hline $\begin{array}{c}\text { Green } \\
\text { Advertising }\end{array}$ & 0.658 & 0.001 \\
\hline
\end{tabular}

\subsubsection{Multicollinearity Test}


Based on table 3, the regression equation is:

$$
\mathrm{Y}=1.825+0.718 \quad \mathrm{X} 1+0.658 \mathrm{X} 2+\mathrm{e}
$$

The regression equation in this study has a constant of 1.825, which indicates that if the independent variable green product (X1) and green advertising (X2) has a value of 0 , then the value of the dependent variable, i.e., green brand image (Y) is 1.825 . The linear regression coefficient doubles the green product variable $(\mathrm{X} 1)$ is 0.718 , while the green advertising variable (X2) is 0.658 . Thus, with every increase in the value of 1 of the green product variable, the green brand image will increase by 0,718 . So did the green advertising variable value increase; the green brand image will increase by 0.658 , assuming other variables considered constant or fixed.

\subsection{Hypothesis Test}

Hypothesis testing in this study used partial testing, consisting of the t-test, and simultaneous testing with the $\mathrm{F}$ test.

Table 4. T-Test Results

\begin{tabular}{|l|l|l|l|l|}
\hline Variable & $\begin{array}{l}\text { t- } \\
\text { count }\end{array}$ & t-table & Sig & Information \\
\hline $\begin{array}{l}\text { Green } \\
\text { Product } \\
\left(\mathrm{X}_{1)}\right.\end{array}$ & 6,012 & 1,98447 & 0,000 & $\begin{array}{l}\mathrm{H}_{1} \text { accepted, Ho } \\
\text { rejected }\end{array}$ \\
\hline $\begin{array}{l}\text { Green } \\
\text { Advertising } \\
\left(\mathrm{X}_{2}\right)\end{array}$ & 3,335 & 1,98447 & 0,001 & $\begin{array}{l}\mathrm{H}_{2} \text { accepted, Ho } \\
\text { rejected }\end{array}$ \\
\hline
\end{tabular}

Table 4 shows that the green product t-count value is 6.012, and t-table is 1.98447 , which means t-count $>$ t-table, and significant by 0.000 or have a $<$ value of 0.05 . Thus, partially the green product variable has a significant influence on the green brand image. Similarly, the variable green advertising has a value of t-calculated (3.335) > t-table (1.98447), with a significant $r 0.001$ or has a value of $<0.05$, so there is a significant influence on green advertising of green brand image.
Table 5. F-Test Results

\begin{tabular}{|c|c|c|c|c|}
\hline Variable & $\begin{array}{l}\text { F- } \\
\text { count }\end{array}$ & $\begin{array}{l}F_{-} \\
\text {table }\end{array}$ & Sig & Information \\
\hline $\begin{array}{l}\text { Green } \\
\text { Product }\left(\mathrm{X}_{1}\right) \\
\text { and } \\
\text { Green } \\
\text { Advertising } \\
\left(\mathrm{X}_{2}\right) \text { to Green } \\
\text { Brand Image } \\
(\mathrm{Y})\end{array}$ & 80.592 & 23.94 & 0,000 & $\begin{array}{l}\mathrm{H}_{3} \\
\text { accepted, } \\
\text { Ho rejected }\end{array}$ \\
\hline
\end{tabular}

Table 5 shows that value F-count $(80,592)>$ the Ftable (3.94), with a significance of 0.000 or having a value of $<0.05$. Thus, there is a simultaneous influence between green product variables and green advertising on green brand image.

\subsection{Coefficient of Determination}

Table 6. Coefficient Values of Determination

\begin{tabular}{|r|r|r|l|r|}
\hline Type & \multicolumn{1}{|l|}{$\mathrm{R}$} & R Square & $\begin{array}{l}\text { Adjusted } \\
\text { Square }\end{array}$ & $\begin{array}{l}\text { Std. Error of } \\
\text { the Estimate }\end{array}$ \\
\hline 1 & $.790^{\mathrm{a}}$ & .624 & .617 & 2.87826 \\
\hline
\end{tabular}

a. Predictors: (Constant), Green Products and Green Advertising

b. Dependent Variable:

Green Brand Image

Based on the value of the coefficient of determination $\left(\mathrm{R}^{2}\right)$ in table 6 , it shows that the influence of independent variables, consisting of green products and green advertising is 0.624 or $62.4 \%$. Thus, $62.4 \%$ of green brand image variations were influenced by both independent variables in this study. The rest can be said to be influenced by other variables that were not studied in this study. While the R-value obtained in this study was 0.790 , this correlation value based on the R-value interpretation table is intense relationship levels.

\subsection{Discussion}

The hypothesis test results show that both green products and advertising were positively associated with a green brand image by young consumers, both partially and simultaneously. That result is in line with the results of previous studies on the interrelationship of the three variables [15]-[17].

In green product variables, young consumers especially give a high assessment of the packaging and 
perception of green products. Green packaging is environmentally oriented packaging, which is not made of plastic materials and can be recycled [17]. In line with the category of green products, which consist of products that are safe to consume and do not produce pollution, efficient in energy use, recyclable, and the use of environmentally oriented production process technology [21].

In addition to packaging, descriptively, young consumers also give a high assessment of the perception of green products. This positive perception illustrates young consumers' awareness of green products. Consumers' perception of the environment will provide the most significant insight into consumer awareness of the environment [5]. The assessment exerts an influence on the image of green brands/companies in the minds of young consumers.

Support is also provided to campaigns for green advertising by the company. Green advertising refers to product promotion messages that support consumers to care about the environment [17]. Descriptively, young consumers rate the green brand image consistent with an invitation to environmental care through delivered advertising and information that the company's products are eco-friendly. That is in line with the high assessment of young consumers on the indicator of maker image and product image on variable green brand image.

However, it is interesting that in young consumers, green brand image has the highest rating on the user's image, especially concerning lifestyle fulfilment. Young consumers feel that product purchases are not consistently interpreted as an environmental concern or penchant for the product. It can be attributed to the motives of young consumers in building perceptions and attitudes towards leading brands, as well as consuming food and beverages, as a form of entertainment and selfexpression, social networking, and prestige [22].

It shows that the positive attitude of consumers towards the environment does not necessarily mean the decision to buy green products unless this attitude is supported by a strong personal commitment to the environment [7]. However, in general, the findings in this study show the linkage of green brand image in the minds of young consumers with how companies are consistent in producing green products and campaigning for environmental concerns through advertising.

\section{CONCULSION}

This study provides empirical support to the interconnectedness of green products and advertising on the formation of green brand image in young consumers in developing countries. Further study development is needed by associating green brand images with the actual behaviour of young consumers purchases on the consumption of green products. Practically, this study supports companies in educating young consumers about environmental concerns and the importance of using green products in promotional activities carried out. Celebrity effects can be used to campaign for green products in young consumers to encourage consumer attitudes on the 'beneficial' behaviour of green product consumption.

\section{REFERENCES}

[1] I. Manisalidis, E. Stavropoulou, A. Stavropoulos, and E. Bezirtzoglou, "Environmental and Health Impacts of Air Pollution: A Review," Frontiers in Public Health, vol. 8, Feb. 2020, doi: 10.3389/fpubh.2020.00014.

[2] R. Yadav and G. S. Pathak, "Young consumers' intention towards buying green products in a developing nation: Extending the theory of planned behavior," Journal of Cleaner Production, vol. 135, Nov. 2016, doi: 10.1016/j.jclepro.2016.06.120.

[3] T. Chen and L. Chai, "Attitude towards the environment and green products: Consumers' perspective," Management Science and Engineering, vol. 4, no. 2, 2010.

[4] D. H. Jayani and A. Mutia, "5 Alasan Konsumen Belanja Produk Ramah Lingkungan," https://databoks.katadata.co.id, Aug. 24, 2021 https://databoks.katadata.co.id/datapublishembe d/122304/5-alasan-konsumen-belanja-produkramah-lingkungan (accessed Oct. 10, 2021).

[5] A. Wijaya, J. Wulandari, and P. Nugeraha, "Kajian Tentang Keputusan Pembelian Produk Ramah Lingkungan dalam Perspektif Theory of Planned Behavior," Jurnal Sosial Humaniora, vol. 11, no. 2, 2020, doi: 10.30997/jsh. v11i2.2658.

[6] R. Supriyanto, F. Mandasari, and A. K. Yapie, "Consumer Behavior Model for Green Product Consumption: Determinant and Impact of Green Satisfaction on Green Loyalty," Proceeding of International ..., no. April, 2019.

[7] C. N. L. Tan, A. O. Ojo, and R. Thurasamy, "Determinants of green product buying decision among young consumers in Malaysia," Young Consumers, vol. 20, no. 2, 2019, doi: 10.1108/YC-12-2018-0898.

[8] R. B. Lestari and Kardinal, "Minat Beli Produk Hijau pada Generasi Milenial," Jurnal Ilmiah Ekonomi Global Masa Kini, vol. 9, no. 2, 2018.

[9] J. Paul, A. Modi, and J. Patel, "Predicting green product consumption using theory of planned behavior and reasoned action," Journal of Retailing and Consumer Services, vol. 29, Mar. 2016, doi: 10.1016/j.jretconser.2015.11.006.

[10] Y. Joshi and Z. Rahman, Factors Affecting Green Purchase Behaviour and Future Research Directions, vol. 3, no. 1-2. Holy Spirit University of Kaslik, 2015. doi: 10.1016/j.ism.2015.04.001. 
[11] E. Muslim and D. R. Indriani, "Analisis Pengaruh Eco-Label terhadap Kesadaran Konsumen untuk Membeli Green Product," Jurnal Manajemen Teknologi, vol. 13, no. 1, pp. 86-100, 2014, doi: 10.12695/jmt.2014.13.1.6.

[12] F. Varah, M. Mahongnao, B. Pani, and S. Khamrang, "Exploring young consumers' intention toward green products: applying an extended theory of planned behavior," Environment, Development and Sustainability, vol. 23, no. 6, Jun. 2021, doi: 10.1007/s10668020-01018-z.

[13] I. Naderi and E. van Steenburg, "Me first, then the environment: young Millennials as green consumers," Young Consumers, vol. 19, no. 3, pp. 280-295, Aug. 2018, doi: 10.1108/YC-082017-00722.

[14] Y. S. Chen, "The drivers of green brand equity: Green brand image, green satisfaction, and green trust," Journal of Business Ethics, vol. 93, no. 2, pp. 307-319, May 2010, doi: 10.1007/s10551-009-0223-9.

[15] S. Avrinella Silaban, S. Sinulingga, and C. Author, "The Effect of Green Marketing on Purchase Decisions and Brand Image as Intervening Variables (Case Study at: Pt. Sari Coffee Indonesia - Starbucks Focal Point Medan)," International Journal of Research and Review (ijrrjournal.com), vol. 8, p. 1, 2021.

[16] D. P. Alamsyah, N. A. Othman, and H. A. A. Mohammed, "The awareness of environmentally friendly products: The impact of green advertising and green brand image," Management Science Letters, vol. 10, no. 9, pp. 1961-1968, 2020, doi: 10.5267/J.MSL.2020.2.017.

[17] H. Purnama, "The effect of green packaging and green advertising on brand image and purchase decision of Teh Kotak product," 2019. doi: 10.2991/insyma-19.2019.34.

[18] C. D’Souza, M. Taghian, P. Lamb, and R. Peretiatkos, "Green products and corporate strategy: an empirical investigation," Society and Business Review, vol. 1, no. 2, pp. 144157, May 2006, doi: 10.1108/17465680610669825.

[19] P. BSingh and K. K. Pandey, "Green Marketing: Policies and Practices for Sustainable Development," Integral Review-A Journal of Management, vol. 5, no. 1, 2012, Accessed: Oct. 11, 2021. [Online]. Available: http://sbinfocanada.about.com

[20] X. Guo Li, X. Wang, and Y. Juan Cai, "Corporate-, Product-, and User-Image Dimensions and Purchase Intentions the Mediating Role of Cognitive and Affective Attitudes," 2011, doi: 10.4304/jcp.6.9.18751879.

[21] N. R. Dianti and E. L. Paramita, "Green Product dan Keputusan Pembelian Konsumen Muda,"
Jurnal Samudra Ekonomi dan Bisnis, vol. 12, no. 1, Jan. 2021, doi: 10.33059/jseb. v12i1.2301.

[22] S. Vaux Halliday and A. Astafyeva, "Millennial cultural consumers: co-creating value through brand communities," Arts Marketing: An International Journal, vol. 4, no. 1/2, 2014, doi: 10.1108/am-01-2014-0003. 